\title{
STUDI FAKTOR PENGHAMBAT PELAKSANAAN KONSTRUKSI DI DAERAH ISTIMEWA YOGYAKARTA
}

\author{
Harry Kurniawan \\ Dosen Tetap Program Studi Teknik Sipil \\ Universitas Riau Kepulauan Batam
}

\begin{abstract}
Abstrak :
Menurut Peraturan Presiden Nomor 70 tahun 2012 Pasal 120 tentang Pengadaan Barang/Jasa Pemerintah, menyatakan bahwa "Selain perbuatan atau tindakan sebagaimana dimaksud dalam Pasal 118 ayat (1), Penyedia Barang/Jasa yang terlambat menyelesaikan pekerjaan dalam jangka waktu sebagaimana ditetapkan dalam Kontrak karena kesalahan Penyedia Barang/Jasa, dikenakan denda keterlambatan sebesar 1/1000 (satu perseribu) dari nilai Kontrak atau nilai bagian Kontrak untuk setiap hari keterlambatan". Maka berdasarkan peraturan diatas peneliti mengadakan penelitian tentang faktor penghambat pelaksanaan konstruksi dan mempercepat pelaksanaan konstruksi di Daerah Istimewa Yogyakarta. Pada penelitian ini menggunakan kuisioner yang ditujukan kepada kontraktor dan konsultan proyek konstruksi di Daerah Istimewa Yogyakarta.Kuisioner yang telah didapat berjumlah 41 dari 60 kuisioner yang telah disebar. Pengolahan data dilakukan untuk mendapatkan persentase, nilai rata-rata (mean), dan nilai simpangan baku. Analisis yang digunakan adalah analisis pemeringkatan nilai rata - rata dan analisis korelasi Pearson. Berdasarkan hasil analisis didapatkan faktor lingkungan proyek sebagai faktor penghambat pelaksanaan konstruksi. Faktor penghambat pelaksanaan konstruksi ditinjau dari faktor lingkungan proyek yang disetujui responden adalah tidak adanya pengertian bersama. Sedangkan untuk mengatasi keterlambatan pelaksanaan konstruksi dengan cara mempercepat pelaksanaan konstruksi adalah keandalan alat ditinjau dari faktor peralatan disetujui sebagian besar responden dapat mempercepat pelaksanaan konstruksi. Hasil analisis korelasi pearson menunjukkan tidak ada hubungan antara hambatan pelaksanaan konstruksi dengan mempercepat pelaksanaan konstruksi di Daerah Istimewa Yogyakarta.
\end{abstract}

Kata kunci : faktor penghambat, mempercepat pelaksanaan, kontraktor, konsultan

\section{PENDAHULUAN}

Perkembangan pelaksanaan konstruksi di Daerah Istimewa Yogyakarta semakin meningkat dari tahun 2013 sampai dengan tahun 2014. Dengan meningkatnya konstruksi di Daerah Istimewa Yogyakarta, menyebabkan Kota Yogyakarta semakin berkembang dengan adanya pelaksanaan pekerjaan konstruksi.

Namun pelaksanaan pekerjaan konstruksi tidak selalu berjalan dengan lancar. Karena sering ditemukan permasalahan-permasalahan di lapangan yang mengakibatkan pelaksanaan pekerjaan kontruksi menjadi terhambat sehingga sering terjadi keterlambatan dalam penyelesaian pelaksanaan konstruksi. 
Menurut Peraturan Presiden Nomor 70 tahun 2012 Pasal 120 menyatakan bahwa "Selain perbuatan atau tindakan sebagaimana dimaksud dalam Pasal 118 ayat (1), Penyedia Barang/Jasa yang terlambat menyelesaikan pekerjaan dalam jangka waktu sebagaimana ditetapkan dalam Kontrak karena kesalahan Penyedia Barang/Jasa, dikenakan denda keterlambatan sebesar 1/1000 (satu perseribu) dari nilai Kontrak atau nilai bagian Kontrak untuk setiap hari keterlambatan”.

Berdasarkan hal-hal tersebut, maka penelitian ini bertujuan untuk menentukan faktor-faktor penghambat pelaksanaan konstruksi dan faktor-faktor mengatasi keterlambatan pelaksanaankonstruksi yang dilakukan dengan mempercepat pelaksanaan pekerjaan konstruksi di Daerah Istimewa Yogyakarta. Dan untuk menentukan hubungan antara faktor-faktor penghambat pelaksanaan konstruksi dengan faktor-faktor mengatasi keterlambatan pelaksanaan konstruksi dilakukan dengan mempercepat pelaksanaan pekerjaan konstruksi di Daerah Istimewa Yogyakarta

\section{TINJAUAN PUSTAKA}

\section{Tujuan Pelaksanaan Konstruksi}

Menurut Ervianto (2005), menyatakan bahwa pada tahap pelaksanaan konstruksi bertujuan untuk mewujudkan bangunan yang dibutuhkan oleh pemilik proyek dan sudah dirancang oleh konsultan perencana dalam batasan biaya dan waktu yang telah disepakati, serta dengan mutu yang telah diisyaratkan.

\section{Material Konstruksi}

Menurut Ervianto (2004) menyatakan pemakaian material merupakan bagian terpenting yang mempunyai persentase cukup besar dari total biaya proyek. Dari beberapa penelitian menyatakan bahwa biaya material menyerap $50 \%$ - $70 \%$ dari biaya proyek, biaya ini belum termasuk biaya penyimpanan material.

Untuk menjamin manajemen material yang benar, setiap proses berikut ini harus benar-benar dilaksanakan secara efektif.

Kegagalan dalam menjalankan satu proses atau lebih akan menyebabkan kegagalan menyeluruh dari manajemen material dan akan menghasilkan sebuah proyek konstruksi yang mahal. Adapun proses dalam manajemen material adalah sebagai berikut :

- Pemilihan material.

- Pemilihan pemasok material.

- Pembelian material.

- Pengiriman material.

- Penerimaan material.

- Penyimpanan material.

- Pengeluaran material.

- Menjaga tingkat persediaan. 


\section{Peralatan Konstruksi}

Ervianto (2004) menyatakan peralatan konstruksi merupakan salah satu dari sumberdaya yang harus disediakan bagi pelaksanaan proyek selain pekerja, metode konstruksi, uang dan material.

Kriteria terpenting dalam memilih tipe dan ukuran alat adalah biaya keseluruhan dari tiap satuan produksi yang diperoleh. Pilihan yang memberikan biaya satuan produksi terkecil kemungkinan adalah pilihan terbaik. Menurut Ervianto (2004), terdapat beberapa faktor lain yang perlu diperhatikan sebelum keputusan akhir dibuat, faktor-faktor tersebut meliputi :

- Keandalan alat.

- Kubutuhan pelayanan.

- Ketersediaan suku cadang.

- Kemudahan pemeliharaan yang dapat dilakukan.

- Kemampuan alat untuk digunakan dalam berbagai macam kondisi lapangan.

- Kemudahan untuk diangkut atau dipindahkan.

- Prospek masa depan pekerjaan untuk alat.

- Permintaan akan alat dan harga penjualannya kembali.

- Tenggang waktu dalam penyerahan alat.

\section{Tenaga Kerja}

Tenaga kerja konstruksi adalah setiap orang yang melakukan pekerjaan perencanaan, pelaksanaan atau pengawasan yang mencakup pekerjaan arsitektural, sipil, mekanikal, elektrikal, dan tata lingkungan masing-masing beserta kelengkapannya, untuk mewujudkan suatu bangunan atau bentuk fisik lain baik untuk memenuhi kebutuhan sendiri maupun untuk masyarakat (UU 13, 2003; UU 18, 1999). Untuk merencanakan tenaga kerja yang realitis perlu diperhatikan bermacam-macam faktor, di antaranya yang terpenting adalah seperti berikut ini :

- Produktivitas tenaga kerja.

- Tenaga kerja periode puncak.

- Jumlah tenaga kerja kantor pusat.

- Perkiraan jumlah tenaga kerja konstruksi di lapangan.

- Meratakan jumlah tenaga kerja guna mencegah gejolak yang tajam.

\section{Metode Konstruksi}

Menurut Ervianto (2004), metode konstruksi bertujuan untuk menguji setiap tahap kegiatan dan menjadikan tahap tersebut lebih mudah dan efektif dalam proses produksi. Untuk mencapai kondisi yang terbaik dari suatu kegiatan dapat dilakukan beberapa cara sebagai berikut : 
1. Memperbaiki lokasi bekerja/lingkungan kerja.

2. Memperbaiki prosedur kerja.

3. Memperbaiki spesifikasi produk.

4. Memperbaiki penggunaan material, alat dan pemakaian pekerja.

\section{Biaya Konstruksi}

Menurut Soeharto (2002), menyatakan perkiraan biaya adalah seni memperkirakan kemungkinan jumlah biaya yang diperlukan untuk kegiatan yang didasarkan atas informasi yang tersedia waktu. Perkiraan biaya ini erat hubungannya dengan analisis biaya, yaitu pekerjaan yang menyangkut pengkajian biaya kegiatankegiatan terdahulu yang akan dipakai sebagai bahan untuk menyusun perkiraan biaya.

\section{Lingkungan}

Menurut Soeharto (2002), dalam bukunya berjudul "Studi Kelayakan proyek" menyatakan bahwa masalah lingkungan hidup saat ini semakin mendapatkan perhatian, karena implementasi fisik proyek dan operasi instalasi nantinya sering membawa perubahan yang dapat mempengaruhi kelestarian lingkungan.

\section{Motivasi}

Menurut Ervianto (2005), menyatakan dalam teori hierarki kebutuhan (need hierarchi theory) yang dikemukakan Abraham Maslow dikatakan bahwa kebutuhan manusia tersusun dalam bentuk hierarki, berawal dari kebutuhan yang palingdasar hingga kebutuhan yang paling tinggi dan apabila seperangkat kebutuhan terpenuhi maka kebutuhan tersebut tidak lagi bisa berfungsi sebagai motivator.

\section{Keterlambatan Pelaksanaan Konstruksi}

Menurut Hajek (1994), apabila kontraktor melakukan kelalaian dalam pelaksanaan konstruksi dalam kontrak, maka pemilik wajib segera mengisyaratkan bahwa akan diambil suatu tindakan, atau pemilik akan membahayakan haknya dalam pengadaan tersebut. Keterlambatan (delay) dapat dimaafkan jika disebabkan oleh keadaaan di luar kekuasaan kontraktor.

Menurut Alifen et al. (2000), keterlambatan pelaksanaan konstruksi sering kali menjadi sumber perselisihan dan tuntutan antara pemilik dan kontraktor, sehingga akan menjadi sangat mahal nilainya baik ditinjau dari sisi kontraktor maupun pemilik. Kontraktor akan terkena denda penalti sesuai dengan kontrak, disamping itu kontraktor juga akan mengalami tambahan biaya overhead selama proyek masih berlangsung. Dari sisi pemilik, keterlambatan proyek akan membawa dampak pengurangan pemasukan karena penundaan pengoperasian fasilitasnya. 


\section{METODE PENELITIAN}

\section{Isi Kuisioner}

Isi dari kuisioner adalah pertanyaan-pertanyaan tentang fakta-fakta yang sebagai penghambat dan mempercepat pelaksanaan konstruksi di Daerah Istimewa Yogyakarta menurut responden.

Daftar pertanyaan pada kuisioner terdiri dari 3 bagian, yaitu : (1) Data Perusahaan, meliputi nama perusahaan, umur perusahaan dan type proyek konstruksi yang ditangani. (2) Data Responden, meliputi nama Responden, jabatan, umur, pendidikan terakhir dan lama bekerja. Sedangkan daftar pertanyaan kuisioner berisikan tentang faktor penghambat pelaksanaan konstruksi dan faktor mempercepat pelaksanaan konstruksi di Daerah Istimewa Yogyakarta.

\section{Metode Analisis}

Setelah mendapatkan data kemudian melakukan metode analisis untuk mendapatkan tujuan dari peneltian ini. Metode analisis pada penelitian ini dengan cara (1) Analisis Deskriptif, (2) Pemeringkatan berdasarkan hasil jawaban dari responden pada pertanyaan-pertanyaan tentang faktor-faktor penghambat pelaksanaan dan mempercepat pelaksanaan konstruksi di Daerah Istimewa Yogyakarta, (3) analisis hubungan antara faktor penghambat pelaksanaan konstruksi dengan mempercepat pelaksanaan konstruksi.

\section{ANALISIS DAN PEMBAHASAN}

\section{Deskripsi Perusahaan}

Pada penelitian didapatkan 36 perusahaan yang berpatisipasi dalam pengisian kuisioner penelitian ini. (1)

Berdasarkan umur perusahaan didapatkan data yaitu $0-5$ tahun $(9,756 \%), 6-10$ tahun (14,634 \%), 11 - 15 tahun (19,512\%), 16 - 20 tahun (12,195\%), 21 - 25 tahun $(4,878 \%)$ dan $>25$ tahun $(39,024 \%)$. (2) Berdasarkan type proyek yang ditangani didapatkan data yaitu bangunan transportasi $(12,195 \%)$, bangunan gedung $(58,537 \%)$, bangunan pengairan $(12,195 \%)$ dan perumahan $(17,073 \%)$.

\section{Deskripsi Responden}

Pada penelitian ini didapatkan 41 (Empat Puluh Satu) Responden yang berpartisipasi dalam pengisian kuisioner pada penelitian ini. (1) Berdasarkan umur responden didapatkan data yaitu 21 - 30 tahun (19,512\%), 31 - 40 tahun (41,463 $\%), 41$ - 50 tahun $(19,512 \%)$ dan > 50 tahun $(19,512 \%)$. (2) Berdasarkan pendidikan didapatkan data yaitu SMA (0 \%), D3 (14,634 \%), S1 (73,171\%), S2 $(12,195 \%)$ dan S3 (0 \%). (3) Berdasarkan jabatan didapatkan data yaitu direktur $(21,951 \%)$, manager/ manager rendal/ project manager $(12,195 \%)$, site manager $(17,073 \%)$, kepala divisi/koordinator/kepala bagian (12,195\%), staf teknik/ site 
engineer $(12,195 \%)$, pengawas/ pelaksana $(12,195 \%)$ dan lain-lain $(12,195 \%)$. (4) Berdasarkan lama bekerja didapat data yaitu 0 - 5 tahun $(24,390 \%), 6$ - 10 tahun $(34,146 \%), 11-15$ tahun (14,634 \%), 16 -20 tahun (9,756 \%), $21-25$ tahun $(2,439$ $\%)$ dan $>25$ tahun $(14,634 \%)$.

\section{Faktor Penghambat pelaksanaan konstruksi ditinjau dari faktor tenaga kerja}

Hasil analisis faktor penghambat pelaksanaan konstruksi dijelaskan pada tabel 1 sebagai berikut :

Tabel 1. Faktor Penghambat Pelaksanaan Konstruksi

\begin{tabular}{|c|c|c|c|c|}
\hline Kode & Faktor Penghambat Pelaksanaan & Mean & $\begin{array}{l}\text { Standar } \\
\text { deviasi }\end{array}$ & Ranking \\
\hline V42 & Tidak adanya pengertian bersama & 3,78 & 1,04 & 1 \\
\hline V39 & Adanya konflik kepentingan & 3,76 & 1,09 & 2 \\
\hline V4 & $\begin{array}{l}\text { Perkiraan jumlah tenaga kerja } \\
\text { konstruksi di lapangan. }\end{array}$ & 3,66 & 1,11 & 3 \\
\hline V41 & \begin{tabular}{lll|}
$\begin{array}{l}\text { Adanya pertentangan lama yang } \\
\text { belum terselesaikan }\end{array}$ & \\
\end{tabular} & 3,66 & 1,17 & 4 \\
\hline V40 & Adanya hambatan komunikasi & 3,61 & 1,05 & 5 \\
\hline V38 & Pencemaran lingkungan & 3,39 & 1,09 & 6 \\
\hline V20 & $\begin{array}{lcr}\text { Pemberi tugas yang mungkin } \\
\text { memasok bahan tertentu untuk } \\
\text { digunakan oleh kontraktor }\end{array}$ & 3,37 & 1,22 & 7 \\
\hline $\mathrm{V} 2$ & Tenaga kerja periode puncak. & 3,34 & 1,49 & 8 \\
\hline V13 & Utang & 3,29 & 1,29 & 9 \\
\hline
\end{tabular}


Tabel 1. Faktor Penghambat Pelaksanaan Konstruksi

\begin{tabular}{|c|c|c|c|c|}
\hline Kode & Faktor Penghambat Pelaksanaan & Mean & $\begin{array}{l}\text { Standar } \\
\text { deviasi }\end{array}$ & Ranking \\
\hline $\mathrm{V} 21$ & \begin{tabular}{l}
\multicolumn{4}{l}{ Subkontraktor yang mungkin diminta } \\
oleh kontraktor utama untuk \\
memasok bahan \\
berdasarkan kontrak terpisah permanen
\end{tabular} & 3,29 & 1,33 & 10 \\
\hline $\mathrm{V} 8$ & Biaya sub-kontraktor & 3,24 & 1,16 & 11 \\
\hline V5 & $\begin{array}{l}\text { Meratakan jumlah tenaga kerja guna } \\
\text { mencegah gejolak yang tajam. }\end{array}$ & 3,24 & 1,30 & 12 \\
\hline $\mathrm{V} 1$ & Produktivitas tenaga kerja. & 3,22 & 1,41 & 13 \\
\hline V16 & Pemantauan pengiriman material & 3,12 & 1,23 & 14 \\
\hline V36 & $\begin{array}{l}\text { Mengkoordinasikan seluruh kegiatan } \\
\text { pembangunan, baik untuk bangunan } \\
\text { sementara maupun } \\
\text { permanen, serta semua fasilitas dan } \\
\text { perlengkapan terpasang }\end{array}$ & 3,12 & 1,27 & 15 \\
\hline $\mathrm{V} 12$ & Modal sendiri & 3,12 & 1,31 & 16 \\
\hline V37 & $\begin{array}{l}\text { Mengkoordinasikan para } \\
\text { subkontraktor }\end{array}$ & 3,10 & 1,16 & 17 \\
\hline V47 & $\begin{array}{l}\text { Menyediakan kondisi } \\
\text { dengan cara memberikan } \\
\text { akan rasa aman }\end{array}$ & 3,10 & 1,32 & 18 \\
\hline V14 & Perkiraan jumlah keperluan material & 3,10 & 1,37 & 19 \\
\hline V22 & Perkiraan jumlah keperluan material & 3,07 & 1,25 & 20 \\
\hline $\mathrm{V7}$ & Biaya bahan langsung. & 3,05 & 1,12 & 21 \\
\hline V23 & Tempat penyimpanan material & 3,05 & 1,16 & 22 \\
\hline V50 & Memenuhi kebutuhan pemeliharaan & 3,05 & 1,18 & 23 \\
\hline V29 & $\begin{array}{l}\text { Subkontraktor yang mungkin diminta } \\
\text { oleh kontraktor utama untuk } \\
\text { memasok bahan permanen } \\
\text { berdasarkan kontrak terpisah }\end{array}$ & 3,05 & 1,30 & 24 \\
\hline $\mathrm{V} 28$ & Keandalan alat & 3,02 & 1,46 & 25 \\
\hline V30 & $\begin{array}{l}\text { Memperbaiki } \\
\text { lingkungan kerja }\end{array}$ & 3,00 & 1,14 & 26 \\
\hline V19 & Fabrikasi material & 3,00 & 1,18 & 27 \\
\hline V31 & Memperbaiki prosedur kerja & 3,00 & 1,24 & 28 \\
\hline V24 & $\begin{array}{l}\text { Kemudahan alat untuk diangkut dan } \\
\text { dipindahkan }\end{array}$ & 2,98 & 1,17 & 29 \\
\hline V25 & $\begin{array}{l}\text { Kemampuan alat untuk } \\
\text { dalam berbagai macam } \\
\text { lapangan }\end{array}$ & 2,98 & 1,33 & 30 \\
\hline
\end{tabular}


Tabel 1. Faktor Penghambat Pelaksanaan Konstruksi

\begin{tabular}{|c|c|c|c|c|}
\hline Kode & Faktor Penghambat Pelaksanaan & Mean & $\begin{array}{l}\text { Standar } \\
\text { deviasi }\end{array}$ & Ranking \\
\hline V48 & $\begin{array}{l}\text { Menyediakan kondisi } \\
\text { dengan cara memberikan } \\
\text { eksistensi }\end{array}$ & 2,95 & 0,97 & 31 \\
\hline V9 & Biaya peralatan & 2,95 & 1,20 & 32 \\
\hline V35 & $\begin{array}{l}\begin{array}{l}\text { Perencanaan dan } \\
\text { organisasi lapangan }\end{array} \\
\end{array}$ & 2,95 & 1,30 & 33 \\
\hline V32 & Memperbaiki spesifikasi produk & 2,93 & 1,10 & 34 \\
\hline V46 & $\begin{array}{l}\text { Menyediakan kondisi } r \\
\text { dengan cara memberikan } \\
\text { penghargaan }\end{array}$ & 2,93 & 1,15 & 35 \\
\hline V33 & $\begin{array}{l}\text { Memperbaiki penggunaan material, } \\
\text { alat dan pemakaian pekerja }\end{array}$ & 2,93 & 1,25 & 36 \\
\hline V34 & $\begin{array}{l}\text { Perencanaan dan pengendalian jadwal } \\
\text { waktu pelaksanaan }\end{array}$ & 2,93 & 1,31 & 37 \\
\hline $\mathrm{V} 10$ & Biaya peralatan & 2,90 & 1,16 & 38 \\
\hline V11 & Biaya umum proyek & 2,90 & 1,18 & 39 \\
\hline V43 & $\begin{array}{l}\text { Menyediakan kondisi motivasi } \\
\text { dengan cara memberikan pengetahuan } \\
\text { mengenai hasil kerja }\end{array}$ & 2,88 & 1,08 & 40 \\
\hline V18 & Spesifikasi material yang digunakan & 2,88 & 1,23 & 41 \\
\hline V17 & $\begin{array}{l}\text { Uji coba yang harus dilakukan } \\
\text { terhadap material yang digunakan } \\
\text { sebelum material diterima }\end{array}$ & 2,88 & 1,27 & 42 \\
\hline $\mathrm{V} 15$ & Tempat penyimpanan material & 2,85 & 1,11 & 43 \\
\hline V6 & Biaya tenaga kerja langsung & 2,85 & 1,20 & 44 \\
\hline V49 & $\begin{array}{l}\text { Menyediakan kondisi } \\
\text { dengan cara melalui perencanaan dan } \\
\text { pengorganisasian } \\
\text { seksasama }\end{array}$ & 2,83 & 1,09 & 45 \\
\hline V45 & $\begin{array}{l}\text { Menyediakan } \\
\text { dengan cara } \\
\text { fisiologis }\end{array}$ & 2,80 & 1,12 & 46 \\
\hline V3 & Jumlah tenaga kerja kantor pusat. & 2,76 & 1,11 & 47 \\
\hline $\mathrm{V} 26$ & Tempat penyimpanan peralatan & 2,76 & 1,18 & 48 \\
\hline V27 & Kemudahan pemeliharaan peralatan & 2,76 & 1,18 & 49 \\
\hline V44 & $\begin{array}{l}\text { Menyediakan kondisi } \\
\text { dengan cara memberikan } \\
\text { aktualisasi diri }\end{array}$ & 2,71 & 1,05 & 50 \\
\hline
\end{tabular}

Sumber : Pengolahan Data Primer, 2014 
Berdasarkan tabel 1 tidak adanya pengertian bersama sebagai faktor penghambat pelaksanaan konstruksi ditinjau dari faktor lingkungan proyek pada peringkat pertama disetujui sebagian besar responden merupakan faktor penghambat pelaksanaan konstruksi dengan nilai mean 3,78 dan standar deviasi 1,04.

Adanya konflik kepentingan sebagai faktor penghambat pelaksanaan konstruksi ditinjau dari faktor lingkungan proyek berada pada peringkat kedua sebagai faktor penghambat pelaksanaan konstruksi dengan nilai mean 3,76 dan standar deviasi 1,09 .

\section{Mempercepat Pelaksanaan Konstruksi}

Hasil dari analisis faktor mempercepat pelaksanaan konstruksi berdasarkan pendapat responden pada penelitian ini dijelaskan pada tabel 2 sebagai berikut:

Tabel 2. Faktor Mempercepat Pelaksanaan Konstruksi

\begin{tabular}{|c|c|c|c|c|}
\hline Kode & Faktor Mempercepat Pelaksanaan & Mean & $\begin{array}{c}\text { Standar } \\
\text { deviasi }\end{array}$ & Ranking \\
\hline W28 & Keandalan alat & 3,98 & 0,99 & 1 \\
\hline $\mathrm{W} 1$ & Produktivitas tenaga kerja & 3,88 & 1,10 & 2 \\
\hline W47 & $\begin{array}{l}\text { Menyediakan kondisi } \\
\text { dengan cara memberikan } \\
\text { akan rasa aman }\end{array}$ & 3,83 & 0,92 & 3 \\
\hline W36 & $\begin{array}{l}\text { Mengkoordinasikan seluruh kegiatan } \\
\text { pembangunan, baik untuk bangunan } \\
\text { sementara maupun bangunan } \\
\text { permanen, serta semua fasilitas dan } \\
\text { perlengkapan terpasang }\end{array}$ & 3,83 & 1,02 & 4,5 \\
\hline W35 & $\begin{array}{ll}\text { Perencanaan dan pengendalian } \\
\text { organisasi lapangan }\end{array}$ & 3,83 & 1,02 & 4,5 \\
\hline W19 & Fabrikasi material & 3,78 & 0,96 & 6 \\
\hline W34 & $\begin{array}{l}\text { Perencanaan dan pengendalian jadwal } \\
\text { waktu pelaksanaan }\end{array}$ & 3,78 & 1,01 & 7 \\
\hline W14 & Perkiraan jumlah keperluan material & 3,78 & 1,06 & 8 \\
\hline W25 & $\begin{array}{l}\text { Kemampuan alat untuk } \begin{array}{r}\text { digunakan } \\
\text { dalam berbagai macam } \\
\text { lapangan }\end{array} \\
\text { kondisi }\end{array}$ & 3,76 & 0,97 & 9 \\
\hline $\mathrm{W} 2$ & Tenaga kerja periode puncak & 3,76 & 1,09 & 10 \\
\hline W22 & Perkiraan jumlah keperluan peralatan & 3,71 & 0,93 & 11 \\
\hline W7 & Biaya bahan langsung & 3,68 & 0,85 & 12 \\
\hline W12 & Modal sendiri & 3,68 & 1,01 & 13 \\
\hline W37 & $\begin{array}{l}\text { Mengkoordinasikan para } \\
\text { subkontraktor }\end{array}$ & 3,68 & 1,01 & 14 \\
\hline W4 & $\begin{array}{l}\text { Perkiraan jumlah tenaga kerja } \\
\text { konstruksi di lapangan }\end{array}$ & 3,68 & 1,08 & 15 \\
\hline
\end{tabular}


Tabel 2. Faktor Mempercepat Pelaksanaan Konstruksi

\begin{tabular}{|c|c|c|c|c|}
\hline Kode & Faktor Mempercepat Pelaksanaan & Mean & $\begin{array}{c}\text { Standar } \\
\text { deviasi }\end{array}$ & Ranking \\
\hline W6 & Biaya tenaga kerja langsung & 3,63 & 0,97 & 16 \\
\hline W31 & Memperbaiki prosedur kerja & 3,63 & 1,07 & 17 \\
\hline W50 & Memenuhi kebutuhan pemeliharaan & 3,59 & 0,95 & 18 \\
\hline W18 & Spesifikasi material yang digunakan & 3,59 & 0,97 & 19 \\
\hline W49 & $\begin{array}{lcc}\text { Menyediakan } & \text { kondisi } & \text { motivasi } \\
\text { dengan cara melalui perencanaan dan } \\
\text { pengorganisasian } & \text { kerja } & \text { secara } \\
\text { seksama } & & \\
\end{array}$ & 3,59 & 1,00 & 20 \\
\hline W24 & $\begin{array}{l}\text { Kemudahan alat untuk diangkut dan } \\
\text { dipindahkan }\end{array}$ & 3,59 & 1,09 & 21 \\
\hline W23 & Pemantauan pengiriman peralatan & 3,56 & 0,92 & 22 \\
\hline W27 & Kemudahan pemeliharaan peralatan & 3,56 & 1,00 & 23,5 \\
\hline W33 & $\begin{array}{l}\text { Memperbaiki penggunaan material, } \\
\text { alat dan pemakaian pekerja }\end{array}$ & 3,56 & 1,00 & 23,5 \\
\hline W29 & Ketersediaan suku cadang & 3,56 & 1,10 & 25 \\
\hline W16 & Pemantauan pengiriman material & 3,54 & 1,10 & 26,5 \\
\hline W42 & Tidak adanya pengertian bersama & 3,54 & 1,10 & 26,5 \\
\hline W8 & Biaya sub-kontraktor & 3,51 & 1,03 & 28 \\
\hline W10 & Biaya umum proyek & 3,49 & 0,93 & 29 \\
\hline W15 & Tempat penyimpanan material & 3,49 & 0,95 & 30 \\
\hline W30 & $\begin{array}{l}\text { Memperbaiki } \\
\text { bekerja/lingkungan kerja }\end{array}$ & 3,46 & 0,95 & 31 \\
\hline W45 & $\begin{array}{l}\text { Menyediakan kondisi } \\
\text { dengan cara memberikan } \\
\text { fisiologis }\end{array}$ & 3,46 & 1,03 & 32 \\
\hline W21 & $\begin{array}{l}\text { Subkontraktor yang mungkin diminta } \\
\text { oleh kontraktor utama untuk } \\
\text { memasok bahan permanen } \\
\text { berdasarkan kontrak terpisah }\end{array}$ & 3,46 & 1,07 & 33 \\
\hline W46 & $\begin{array}{l}\text { Menyediakan kondisi } \\
\text { dengan cara memberikan } \\
\text { penghargaan }\end{array}$ & 3,44 & 1,10 & 34 \\
\hline W43 & $\begin{array}{l}\text { Menyediakan kondisi motivasi } \\
\text { dengan cara memberikan pengetahuan } \\
\text { mengenai hasil kerja }\end{array}$ & 3,41 & 0,97 & 35 \\
\hline W32 & Memperbaiki spesifikasi produk & 3,39 & 0,92 & 36 \\
\hline W26 & Tempat penyimpanan peralatan & 3,39 & 1,02 & 37 \\
\hline W13 & Utang & 3,39 & 1,09 & 38 \\
\hline W48 & $\begin{array}{l}\text { Menyediakan kondisi } \\
\text { dengan cara memberikan } \\
\text { eksistensi }\end{array}$ & 3,34 & 0,91 & 39 \\
\hline
\end{tabular}


Tabel 2. Faktor Mempercepat Pelaksanaan Konstruksi

\begin{tabular}{|c|l|c|c|c|}
\hline Kode & Faktor Mempercepat Pelaksanaan & Mean & $\begin{array}{c}\text { Standar } \\
\text { deviasi }\end{array}$ & Ranking \\
\hline W20 & $\begin{array}{l}\text { Pemberi tugas yang mungkin } \\
\text { memasok bahan tertentu untuk } \\
\text { digunakan oleh kontraktor }\end{array}$ & 3,32 & 1,17 & 40 \\
\hline W41 & $\begin{array}{l}\text { Adanya pertentangan lama yang } \\
\text { belum terselesaikan }\end{array}$ & 3,32 & 1,27 & 41 \\
\hline W17 & $\begin{array}{l}\text { Uji coba yang harus dilakukan } \\
\text { terhadap material yang digunakan } \\
\text { sebelum material diterima }\end{array}$ & 3,29 & 0,96 & 42 \\
\hline W9 & Biaya peralatan kn montivasi & 3,24 & 0,92 & 46 \\
\hline W39 & Adanya konflik kepentingan & 3,27 & 0,98 & 43 \\
\hline W40 & Adanya hambatan komunikasi & 3,27 & 1,12 & 44 \\
\hline W44 & $\begin{array}{l}\text { Menyediakan kondisi man cara memberikan kebutuhan } \\
\text { dengan } \\
\text { aktualisasi diri }\end{array}$ & 3,24 & 1,07 & 47 \\
\hline W11 & Biaya umum pusat & 3,24 & 1,09 & 48 \\
\hline W3 & Jumlah tenaga kerja kantor pusat & 3,15 & 1,13 & 49 \\
\hline W5 & $\begin{array}{l}\text { Meratakan jumlah tenaga kerja guna } \\
\text { mencegah gejolak yang tajam }\end{array}$ & 3,10 & 1,09 & 50 \\
\hline W38 & Pencemaran lingkungan & & 45 \\
\hline
\end{tabular}

Sumber : Pengolahan Data Primer, 2014 
Berdasarkan tabel 2 keandalan alat sebagai faktor mempercepat pelaksanaan konstruksi ditinjau dari faktor peralatan pada peringkat pertama yang disetujui sebagian besar responden yang dapat mempercepat pelaksanaan konstruksi dengan nilai mean 3,98 dan standar deviasi 0,99. Pada peringkat kedua terdapat produktivitas tenaga kerja sebagai faktor mempercepat pelaksanan konstruksi ditinjau dari faktor tenaga kerja yang disetujui sebagian besar responden yang dapat mempercepat pelaksanaan konstruksi dengan nilai mean 3,88 dan standar deviasi 1,10.

\section{Analisis hubungan antara faktor penghambat pelaksanaan konstruksi dengan mempercepat pelaksanaan konstruksi.}

Korelasi Pearson adalah suatu bentuk rumus yang digunakan untuk mencari hubungan antara dua variabel, yaitu variabel bebas atau independent variable dan variabel terikat atau dependent variable. Di mana umumnya variabel terikat diberi notasi $\mathrm{Y}$ dan variabel bebas diberi notasi $\mathrm{X}$, di mana variabel bebas ini merupakan pemberian dari hasil suatu pengamatan sehingga variabel bebas tersebut tidak lagi random atau acak.

Hasil analisis hubungan antara faktor penghambat pelaksanaan konstruksi dengan mempercepat Pelaksanaan konstruksi adalah sebagai berikut :

Tabel 3. Nilai Korelasi

\begin{tabular}{|ll|l|l|}
\hline \multicolumn{2}{|c|}{ Correlations } & $\begin{array}{l}\text { Hambatan } \\
\text { Konstruksi }\end{array}$ & $\begin{array}{l}\text { Mempercepat } \\
\text { Konstruksi }\end{array}$ \\
\hline Hambatan Konstruksi & Pearson Correlation & 1 &, 287 \\
& Sig. (2-tailed) &, 069 \\
& N & 41 & 41 \\
\hline Mempercepat Konstruksi & Pearson Correlation &, 287 & 1 \\
& Sig. (2-tailed) &, 069 & \\
& N & 41 & 41 \\
\hline
\end{tabular}

Sumber : Pengolahan Data SPSS,2014 
Berdasarkan pengolahan data SPSS pada tabel 3 didapatkan nilai korelasi pearson sebesar 0,287. Maka dilihat dari tingkat hubungan termasuk korelasi cukup pada interval koefisien 0,26 - 0,50 pada hubungan antara faktor penghambat pelaksanaan konstruksi dengan mempercepat pelaksanaan konstruksi.

Signifikansi pada pengolahan data SPSS didapatkan nilai 0,069 dimana $\alpha$ adalah $5 \%$ maka dapat disimpulkan bahwa tidak ada hubungan antara hambatan pelaksanaan konstruksi dengan mempercepat pelaksanaan konstruksi di Daerah Istimewa Yogyakarta.

\section{KESIMPULAN DAN SARAN}

\section{Kesimpulan}

Berdasarkan dari hasil penelitian berjudul "Studi Faktor Penghambat Pelaksanaan Konstruksi di Daerah Istimewa Yogyakarta" diperoleh hasil kesimpulan sebagai berikut. (1) Tidak adanya pengertian bersama ditinjau dari faktor lingkungan proyek disetujui sebagian besar responden sebagai faktor penghambat pelaksanaan konstruksi.

(2) Keandalan alat ditinjau dari faktor peralatan disetujui sebagian besar responden dapat mempercepat pelaksanaan konstruksi. (3) Berdasarkan hasil analisis korelasi pearson didapatkan nilai interpelasi 0,287 . Nilai tersebut menyatakan bahwa hubungan antara faktor penghambat pelaksanaan konstruksi dengan mempercepat pelaksanaan konstruksi termasuk pada korelasi cukup pada interval koefisin 0,26 - 0,50. Nilai signifikansi sebesar 0,069, dimana $\alpha$ adalah $5 \%$, maka dapat diketahui bahwa nilai signifikansi lebih besar dari nilai $\alpha$ $(0,069>0,05)$, maka dapat disimpulkan bahwa tidak ada hubungan antara hambatan pelaksanaan konstruksi dengan mempercepat pelaksanaan konstruksi di Daerah Istimewa Yogyakarta.

\section{Saran}

Para jasa konstruksi/ kontraktor disarankan untuk memperhatikan faktor-faktor penghambat dan cara mempercepat pelaksanaan konstruksi. Sehingga para para pelaku jasa konstruksi dapat mencegah terjadinya keterlambatan pelaksanaan konstruksi. Sebagai acuan kepada penelitian selanjutnya tentang faktor penghambat pelaksanaan konstruksi sehingga dapat mengidentifakasi lebih rinci dari faktor-faktor penghambat lainnya.

\section{DAFTAR PUSTAKA}

Alderfer. C., 1972, Existence, Relatedness, \& Growth, Free Pess, New York. Alifen, R, S., Setiawan, R. S., Sunarto, A,. 2000, Analisa "What If" Sebagai Metode Antisipasi Keterlambatan Durasi Proyek, Dimensi Teknik Sipil, Vol. 2 No. 1, Maret. 
Ervianto, W.I., 2005, Manajemen Proyek Konstruksi, Penerbit Andi, Yogyakarta. Ervianto, W.I, 2004, Teori - Aplikasi Manajemen Proyek Konstruksi, Penerbit Andi, Yogyakarta.

Filley, A.C., 1975, Interpersonal Conflict Resolution, Glenview IL : Scott, Foresman.

Hajek, Victor,G., 1994, Manajemen Proyek Perekayasaan Edisi Tiga, Penerbit Erlangga, Jakarta.

Hillway,T., 1956, Introduction To Research, Boston : Houghton Mifflin Co.

Husnan, S., Suwarsono, 1995, Studi Kelayakan Proyek Edisi Ketiga, UPP AMP YKPN,

Yogyakarta.

Husnan, S., Muhammad, S., 2000, Studi Kelayakan Proyek Edisi Keempat, UPP AMP YKPN, Yogyakarta.

Koesmargono, A., Kaming, P.F., Hatmoko, J.T., Suryadharma, H., 2012, Metodologi Penelitian dan Statistika, Hand Out, Program Studi Magister Teknik Sipil, Program Pascasarjana, Universitas Atma Jaya, Yogyakarta.

Nazir, M., 2011, Metode Penelitian, Penerbit Ghalia Indonesia, Bogor.

Reksohadiprodjo, S., 1995, Manajemen Proyek Edisi 3, BPFE, Yogyakarta.

Soeharto, I., 1990, Manajemen Proyek Industri, Penerbit Erlangga, Jakarta.

Soeharto, I., 1995, Manajemen Proyek Dari Konseptual sampai Operasional, Penerbit Erlangga, Jakarta.

Soeharto, I., 1999, Manajemen Proyek Dari Konseptual sampai Operasional Edisi Kedua Jilid 1, Penerbit Erlangga, Jakarta.

Soeharto, I., 2001, Manajemen Proyek Dari Konseptual sampai Operasional Edisi Kedua Jilid 2, Penerbit Erlangga, Jakarta.

Soeharto, I., 2002, Studi Kelayakan Proyek Industri, Penerbit Erlangga, Jakarta.

Soehendradjati, IR.RJB., 1987, Pengantar Manajemen Konstruksi (Bagian 2), Jurusan Teknik Sipil, UGM, Yogyakarta.

Sudjana,. 1992, Metode Statistika, Penerbit Tarsito, Bandung.

Uyanto, Stanislaus,S., 2009, Pedoman Analisis Data dengan SPSS, Penerbit Graha Ilmu, Yogyakarta.

Whitney, F.L., 1960, The Elements of Research, Asian Eds, Osaka : Overseas Book Co.

Widhiawati,Rai,I.A., 2009, Analisis Faktor-faktor Penyebab Keterlambatan Pelaksanaan

Proyek Konstruksi, Staf Pengajar Teknik Sipil, Universitas Udayana.

Wikipedia., 2013, Motivasi, http://id.wikipedia.org/wiki/Motivasi.

\section{PERATURAN PERUNDANG-UNDANGAN}

Peraturan Presiden Nomor 70 tahun 2012 Pasal 120 tentang Perubahan Kedua Atas Peraturan Presiden Nomor 54 Tahun 2010 Pengadaan Barang / Jasa Pemerintah. 